DOI: 10.20472/IAC.2018.044.020

\author{
MUHAMMAD HOQUE \\ University of KwaZulu-Natal, South Africa
}

STHEMBILE MILLICENT NTSELE

University of KwaZulu-Natal, South Africa

\title{
DERTIMINING THE RELATIONSHIP BETWEEN \\ TRANSFORMATIONAL LEADERSHIP AND RISK MANAGEMENT IN THE RETAIL BANK
}

\begin{abstract}
:
Risk Management is one of the most challenges facing the banking industry, after 2008 financial crisis the banking industry has become one of the heavily regulated industries. This study is intending to determine the association between transformational leadership and risk management. This was a cross-sectional study conducted among 42 employees who were working at the retail bank. Census sampling method was used to select the samples. Data were collected using self-administered questionnaire. The present study found that most of participants perceive themselves as transformational leaders, however strongly believe in transactional leadership style. Results revealed that there was a significant relationship between transformational leadership and risk management. It is recommended that managers adopt the transformational leadership style to improve followers' performance. The study can assist bank managerial employees to apply the relevant style when dealing with their followers to mitigate risk in the bank. Efficient risk management depends on the effectiveness of the leader.
\end{abstract}

\section{Keywords:}

Transformational leadership, risk management, retail bank, South Africa

JEL Classification: M19, G21, M10 